\title{
Mechanisms of monocyte recruitment and accumulation
}

\author{
Rishad M Faruqi, Paul E DiCorleto
}

The involvement of the bloodborne monocyte in phenomena related to vascular interactions, including wound healing and atherosclerosis, has been well recognised for several decades. As discussed in detail in several articles in this supplement, the monocyte-derived macrophage has been implicated in multiple aspects of atherosclerotic plaque development (figure). These cells contribute to the formation of fatty streak lesions by ingesting massive amounts of lipid and thus developing into foam cells. The monocyte-derived macrophage is also capable of producing growth factors for vascular smooth muscle cells, thus potentially contributing to the proliferative stages of plaque development. Third, the monocyte/macrophage can generate cytotoxic factors for neighbouring cells, leading to smooth muscle cell and endothelial cell damage and death. Finally, as discussed in the last section of this article, lipid-laden macrophages may emigrate from the vessel wall, leading to further physical damage to the endothelium.

The first step in monocyte recruitment into the vessel wall is the attachment of this bloodborne cell to the endothelium. The adherence of mononuclear cells to the endothelial cells of large vessels during the early stages of experimentally induced atherosclerosis has been seen in several animal model systems..$^{1-8}$ In addition, immunohistochemical analysis of human necropsy and carotid endarterectomy specimens has shown similar involvement of monocytes in early atherosclerotic disease. ${ }^{9-11}$ Detailed studies have been performed on hypercholesterolaemic swine, monkeys, rats, and pigeons. ${ }^{2-8}$ These systems have all yielded highly consistent results - a focal adhesion of monocytes to lesion-prone regions of the vasculature. Topics that are currently under investigation include the nature of the underlying mechanisms regulating the expression of leucocyte adhesion proteins on the endothelial cell surface after activation, the mechanism underlying the induction of adhesion by hypercholesterolaemia, the specificity of this leucocyte adhesion (with little if any involvement of neutrophils), and finally the reason why monocytes adhere to specific regions of the vasculature. We discuss below the molecular events that occur during the process of monocyte adhesion to endothelium, chemotaxis of the monocyte into the vessel wall, and the fate of the arterial macrophage.

\section{Adhesion proteins on monocytes and endothelium}

The activated endothelium expresses several proteins on its surface that make the endothelium more "sticky" to the cellular components of the bloodstream. These cellular components themselves have counterreceptors that bind to the proteins expressed on the endothelium. The adhesion proteins expressed on the endothelial cell surface are broadly categorised into two classes: the selectins, so called because of their structural similarity to lectins (a class of proteins with high affinity binding sites for carbohydrate groups) and adhesion proteins belonging to the immunoglobulin gene superfamily (table).

\section{ENDOTHELIAL SELECTINS}

The selectins are a family of glycoproteins with specific structural moieties in common: an amino terminal lectin-like domain, followed by an epidermal growth factor (EGF)like domain, numerous cysteine-rich tandem motifs (similar to those found in complement regulatory proteins), a transmembrane region, and a short cytoplasmic tail. Hence they have also been termed LECCAMs (lectin, EGF, complement regulatory protein, cell adhesion molecules). These molecules are not present on unstimulated endothelial cells but appear on the surface of the endothelium after activation by several biological response modifiers, such as interleukin-1 (IL-1), bacterial lipopolysaccharide (LPS), thrombin, phorbol esters, and tumour necrosis factor (TNF). To date, two selectins have been found to be associated with the activated endotheliumE-selectin (previously known as endothelial leucocyte adhesion molecule-1 or ELAM-1) and P-selectin (previously known as platelet activation-dependent granule to external membrane protein (PADGEM) or granule membrane protein-140 (GMP-140), first described in platelets).

Endothelial selectin (E-selectin), a $115 \mathrm{kDa}$ protein, was identified, cloned, and characterised by Bevilacqua and coworkers using cytokine-activated human endothelial cells. ${ }^{12}$ The lectin-like domain was postulated to recognise carbohydrate ligands on leucocytes. DiCorleto and de la Motte provided evidence of a role for carbohydrate moieties in monocytic cell adhesion to endothelial cells by demonstrating that this interaction could be inhibited by wheatgerm agglutinin as well as certain phosphorylated disaccharides. ${ }^{13}$ More recently, work with monoclonal antibodies to E-selectin mutant proteins, which lacked specific domains of the molecule, showed that the lectin-like domain was necessary for the binding of monocytic cells to endothelial cells. ${ }^{14}$ The putative ligand for E-selectin has been identified as the carbohydrate structure, 
Endothelial adhesion molecules.

\begin{tabular}{|c|c|c|c|c|c|}
\hline $\begin{array}{l}\text { EC adhesion } \\
\text { protein }\end{array}$ & $\begin{array}{l}\text { Size } \\
(k D a)\end{array}$ & Structure & Ligand & $\begin{array}{l}\text { Ligand } \\
\text { cell type }\end{array}$ & $\begin{array}{l}\text { Time of } \\
\text { maximal } \\
\text { expression } \\
\text { in vitro }\end{array}$ \\
\hline $\begin{array}{l}\text { E-selectin or } \\
\text { ELAM-1 }\end{array}$ & 115 & Selectin & Sialyl-Lewis X & PMN, monocyte & $3-4 \mathrm{~h}$ \\
\hline $\begin{array}{l}\text { P-selectin or } \\
\text { PADGEM or } \\
\text { GMP-140 }\end{array}$ & 140 & Selectin & LNF III & PMN, monocyte & $10-30 \mathrm{~min}$ \\
\hline $\begin{array}{l}\text { VCAM-1 or } \\
\text { INCAM-110 }\end{array}$ & 110 & Ig & $\begin{array}{l}\text { VLA-4 } \\
\left(\beta_{1} \text { integrin }\right)\end{array}$ & $\begin{array}{l}\text { Lymphocyte, } \\
\text { monocyte }\end{array}$ & $4-10 \mathrm{~h}$ \\
\hline $\begin{array}{l}\text { ICAM-1 or } \\
\text { (CD 54) }\end{array}$ & 100 & Ig & $\begin{array}{l}\text { LFA-1 or } \\
\text { CD11a/CD18 } \\
\text { ( } \beta_{2} \text { integrin), } \\
\text { Mac-1 or } \\
\text { CD11b/CD18, } \\
\text { p150,95 or } \\
\text { CD11c/CD18 }\end{array}$ & $\begin{array}{l}\text { Lymphocyte, } \\
\text { monocyte, } \\
\text { PMN }\end{array}$ & $12-24 \mathrm{~h}$ \\
\hline ICAM-2 & 46 & Ig & $\begin{array}{l}\text { LFA-1, } \\
\text { ?Mac-1, } \\
\text { ?p150,95 }\end{array}$ & $\begin{array}{l}\text { Lymphocyte, } \\
\text { monocyte, } \\
\text { PMN }\end{array}$ & Constitutive \\
\hline $\begin{array}{l}\text { Athero- } \\
\text { ELAM } \\
\text { (rabbit) }\end{array}$ & $\begin{array}{r}118 \\
98\end{array}$ & Ig & ?VLA-4 & Monocytes & $\begin{array}{l}8-12 \mathrm{~h} \text { post- } \\
\text { endotoxin } \\
\text { treatment } \\
\text { (in vivo) }\end{array}$ \\
\hline
\end{tabular}

ELAM-1, endothelial leucocyte adhesion molecule; PADGEM/GMP-140, platelet-activationdependent granule to external membrane protein/granule membrane protein-140; VCAM-1/ INCAM 110, vascular cell adhesion molecule-1/inducible cell adhesion molecule 110; ICAM, intercellular adhesion molecule; PMN, polymorphonuclear leucocytes; Ig, immunoglobulin; LNF III, lactose n-fucopentaose III; VLA-4, very late antigen-4; LFA-1, lymphocyte function related antigen-1. (For references see text).
rella is expressed early in the process of lesion development and does not persist in the later stages of the disease. In vivo P-selectin may be involved in the targeting of leucocytes to areas of inflammation by causing immediate adherence of leucocytes to the activated endothelium. This event would slow down the leucocytes in an environment of flowing blood, thereby allowing them to become more tightly adherent for subsequent transmigration through the endothelial cell junctions.

\section{IMMUNOGLOBULIN GENE SUPERFAMILY OF} ADHESION RECEPTORS

These receptors have been so named because they contain several immunoglobulin-like domains. Three such molecules have been cloned and characterised in endothelial cells: vascular cell adhesion molecule-1 (VCAM-1) and intercellular cell adhesion molecule-1 and 2 (ICAM-1 and ICAM-2). Cybulsky and Gimbrone identified a surface glycoprotein present on the endothelium overlying atherosclerotic lesion areas of hypercholesterolaemic rabbits. ${ }^{26}$ They termed this molecule "atheroELAM". The N-terminus of this molecule was sequenced and shown to be identical to that of VCAM-1. Athero-ELAM is therefore thought to be the rabbit homologue of VCAM-1.

VCAM-1 is a glycoprotein initially cloned and characterised by Osborn et al as an inducible endothelial cell surface molecule. ${ }^{27}$ The mature protein contains six potential $\mathrm{N}$-linked glycosylation sites on its extracellular domain. Two alternatively spliced forms have been identified that contain either six or seven immunoglobulin-like domains. ${ }^{28} 29$ VCAM-1 (molecular weight of $100-110 \mathrm{kDa}$ ) is expressed on the surface of activated endothelial cells within two hours of stimulation, peaking at $6-10$ hours and persisting for about 48-72 hours, (appearing somewhat later and lasting longer than E-selectin). The induction requires protein synthesis. Its counter-receptor on leucocytes has been shown to be the $\beta 1$ integrin, very late antigen4 (VLA-4), that is present on lymphocytes and monocytes but not neutrophils. ${ }^{30}$ VCAM-1 is thought to have a role in the adhesion and recruitment of lymphocytes and $N$ monocytes into areas of inflammation. More $N$ recently it has been shown to act in conjunction with ICAM-1 in mediating the adhesion of activated monocytes to resting and cytokine-stimulated endothelium. ${ }^{31}$

ICAM-1 and ICAM-2 also belong to the immunoglobulin gene superfamily and are therefore similar to VCAM-1 in structure. They differ from each other in that ICAM-2 contains only two immunoglobulin-like $\mathbb{D}$ domains compared with ICAM-1 which has five. ${ }^{32}{ }^{33}$ ICAM-1 was first cloned and defined 8 by Staunton and coworkers, who showed it to be a member of the immunoglobulin gene superfamily with a size of $100 \mathrm{kDa}$ in $\risingdotseq$ endothelial cells. ${ }^{32}$ ICAM- 1 is expressed constitutively at low levels on the surface of endothelial cells. Treatment of the endo- 
(A) Role of the blood monocyte in atherogenesis.

(B) Scanning electron micrograph showing monocyte adhesion to

(C) Scanning electron micrograph showing monocyte migration across intact human endothelium.
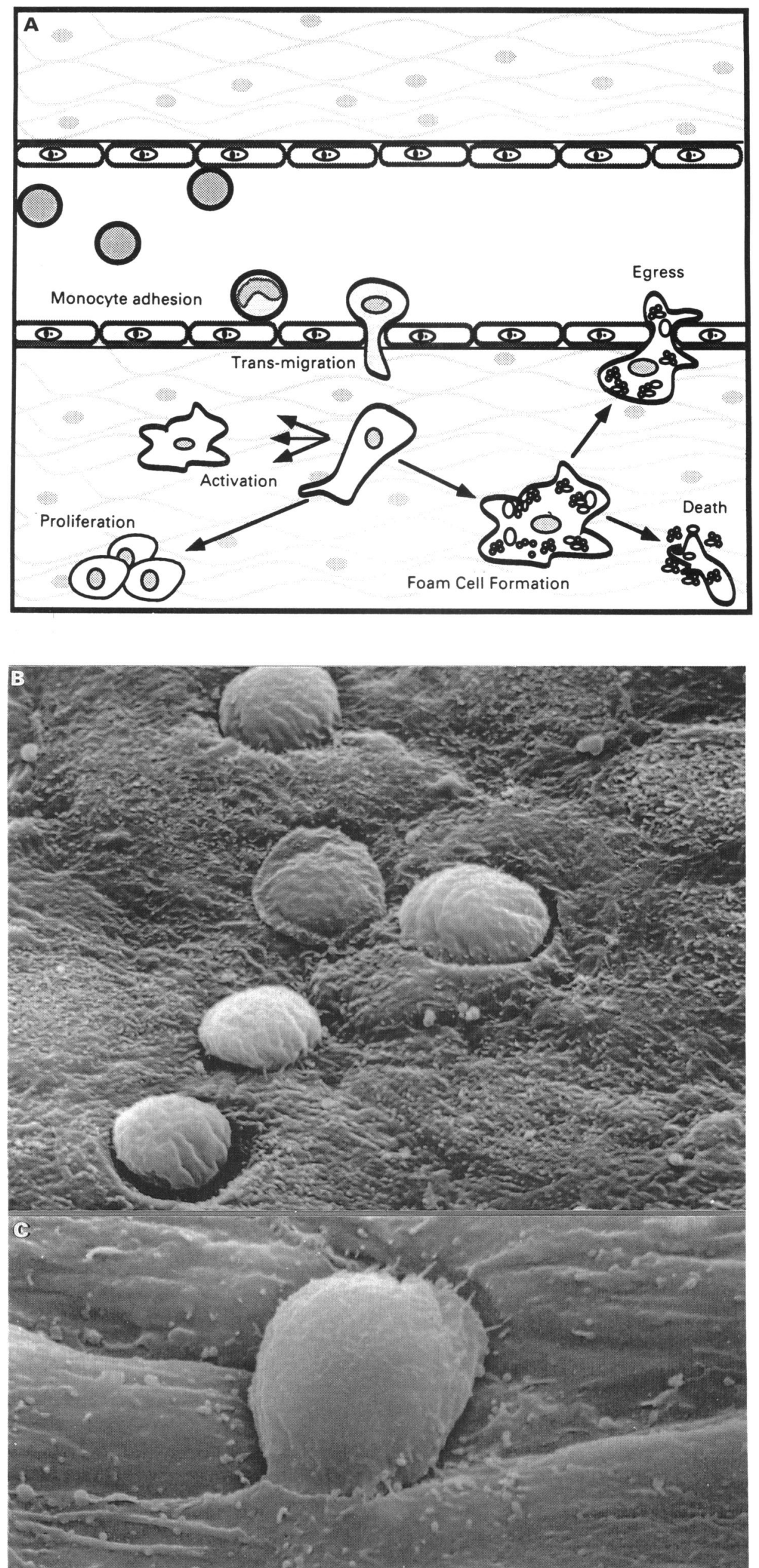
thelial cells with IL- 1 or TNF $a$ induces an increase in the surface expression of ICAM-1, a process that requires de novo protein mRNA synthesis. The induction of ICAM-1 on endothelial cells in response to cytokines occurs within 4-6 hours and reaches a plateau by 24 hours. The counter-receptor to ICAM-1 has been shown to be a $\beta_{2}$ integrin lymphocyte function related antigen1 (LFA-1) that is involved in cell-matrix and cell-cell recognition. ${ }^{34}$ Others have demonstrated the expression of p150,95 and Mac-1 (also members of the $\beta_{2}$ integrin family of receptors) on the surface of monocytes in response to several stimuli. Functional studies have implicated these receptors in monocyte adhesion and diapedesis, and because they are members of the integrin family they may, like LFA-1, mediate their effects via binding to ICAM-1 receptors on endothelial cells. ${ }^{35-37}$ Dustin and Springer have also demonstrated that the interaction between LFA- 1 and ICAM-1 is temperature and energy sensitive. ${ }^{38}$

ICAM-2 was cloned and characterised by Staunton et al using LPS-stimulated endothelial cells from the human umbilical vein. ${ }^{33}$ It was found to be an integral membrane protein expressed constitutively by endothelial cells. The $\mathrm{N}$-terminal domain of ICAM-1 and ICAM-2 are 34\% homologous. ICAM-2 also binds to the integrin LFA-1, and, in view of its $\mathrm{N}$-terminal homology with ICAM-1, possibly interacts with Mac-1 and p150,95 as well. Unlike ICAM-1 its surface expression is not increased by cytokine stimulation of endothelial cells. ${ }^{39} 40$ Both ICAM-1 and ICAM-2 are thought to have a role in the recruitment and adhesion of lymphocytes and monocytes in areas of inflammation. The evidence for their mediation of neutrophil adhesion to endothelium remains controversial.

WHICH ADHESION PROTEINS HAVE A ROLE IN ATHEROGENESIS?

It must be emphasised that much of the information cited above has been derived from in vitro studies. Very little is known about the actual sequence of events leading to monocyte adhesion in vivo, especially in large vessels. As mentioned earlier, the only study showing the kinetics of an inducible endothelial cell surface glycoprotein (athero-ELAM) was performed in a rabbit model. ${ }^{26}$ Other investigators have examined human arterial tissue for the expression of leucocyte adhesion proteins using immunocytochemical techniques. $^{4142}$ ICAM-1 expression was observed on various cell types in human atherosclerotic lesions.

Which, if any, of the above described endothelial cell leucocyte adhesion proteins and their counterpart monocyte receptors are responsible for the adhesion of bloodborne monocytes to lesion-prone regions of the vasculature in human atherogenesis or in any animal model of atherosclerosis remains to be rigorously defined. One reason for our lack of information on the in vivo situation is the transient expression of these molecules which could very well lead to negative findings if the wrong time point is chosen. Secondly, many of the molecular tools for the study of these proteins, including monoclonal antibodies, have been generated against human antigens and as the probes are often species specific, their use in animal models is precluded. One rigorous approach to demonstrating the involvement of a particular adhesion protein in monocyte adhesion to large vessel endothelium would be to inhibit specifically the expression or the binding activity of the adhesion protein by means of either an anti-sense DNA approach or by blocking antibodies in an in vivo experiment. Many laboratories are already conducting such studies.

\section{Modulators of monocyte adhesion to endothelial cells}

STIMULATORS OF MONOCYTE ADHESION

In the past decade several stimulators and inhibitors of leucocyte adhesion to the endothelium have been identified. The effect of these compounds may be mediated by their action on either of the two cell types alone or both together. The atherosclerotic lesion is made up of numerous cell types which may interact with each other in a series of autocrine and paracrine loops thus contributing to the propagation and regression of the pathogenic process. Evidence continues to grow for the presence in arterial tissue of stimulators and inhibitors of both monocyte adhesion to the endothelium and chemotaxis of monocytes into the intima.

The link between hyperlipidaemia and atherosclerosis has long been established. As discussed above, in many diet-induced atherosclerosis models, monocyte adhesion to focal regions of the vasculature occurs as one of the earliest readily documented events in the disease process. Unfortunately, these types of model systems have limited potential in delineating the sequence of events at the cellular and molecular level responsible for hypercholesterolaemia-induced adhesion: thus specific mechanistic questions have been most often investigated in cell culture systems. Bath et al showed that monocytes from hypercholesterolaemic patients adhered in larger numbers to cultured porcine aortic endothelial cells than did monocytes from matched controls. ${ }^{43}$ Oxidised low density lipoprotein (oxLDL), a molecule strongly implicated in the atherogenic process, ${ }^{44}$ has been shown to enhance the adhesion of cells of the human monocytic cell line U937 to cultured endothelium. ${ }^{45}$ Pritchard and coworkers showed that native LDL when added to endothelial cells at "atherogenic" concentrations also increased monocytic cell binding to the endothelial cells. ${ }^{46}$ Minimally modified LDL (mmLDL), ${ }^{47}$ a slightly oxidised LDL preparation, as well as $\beta$ VLDL ${ }^{48} 49$ (a lipoprotein present in high concentrations in hyperlipidaemic animals and type III hypercholesterolaemic humans) have both been shown to significantly increase mono- 
cyte binding to endothelial cells. Similar studies to examine the effects of fish oils on monocyte adhesion remain controversial, with some studies showing an increase in monocyte adhesion while others noted an abrogation of the response. ${ }^{50} 51$

Several studies have shown an increased adhesiveness of the endothelium for leucocytes after treatment with various biological response modifiers including IL-1, TNF $a$, and LPS. ${ }^{52-54}$. IL-1 and TNF $a$ caused a rapid induction of the adhesion molecules $\mathrm{E}$ selectin, VCAM-1, and ICAM-1; whereas IFN $\gamma$ upregulated ICAM-1 over a longer period of time $(10-24 \mathrm{~h}) .{ }^{556}$ DiCorleto and de la Motte showed that the coagulation cascade protease, thrombin, also stimulated monocyte adhesion to endothelial cells. ${ }^{57}$ Certain viral infections of endothelial cells have been shown to increase their adhesiveness to monocytes. Herpes simplex virus-1 (HSV-1) infection of endothelial cells induced an increase in monocyte adhesion within three hours of infection without any noted cytopathic effect. ${ }^{58}$ Similar effects were observed with cytomegalovirus. ${ }^{59}$ Recently, Etingin et al demonstrated that HSV-1-infected endothelial cells mediated monocytic adhesion via P-selectin expression. ${ }^{60}$ These in vitro findings support the possibility of a role for viral infection in the pathogenesis of atherosclerosis as has been proposed by several investigators. ${ }^{61-63}$

Increased monocyte adhesion to the vessel wall may also reflect a change in monocytic gene expression rather than a change in the endothelium. Elliott et al recently showed that monocytes stimulated with IL-3 or granulocyte macrophage-colony stimulating factor (GM-CSF) showed an increased adhesion to endothelial cells with an early $(10 \mathrm{~min})$ and late $(9 \mathrm{~h})$ phase. Both phases could be partially blocked with anti-CD 18 antibodies. ${ }^{64}$ In another study, treatment of endothelial cells with IFN $\gamma$ did not increase their adhesiveness for leucocytes; ${ }^{65}$ however, treatment of monocytes with IFN $\gamma$ significantly increased their binding to resting and IL-1 treated endothelial cells. ${ }^{31}$ Doherty and coworkers showed that the chemotactic factors $\mathrm{C} 5_{\mathrm{a}_{\text {des-arg }}}$ (a complement cascade product) and formylmethionyl-leucyl-phenylalanine (FMLP) (a bacterial product), acted primarily on monocytes and not endothelial cells, increasing their adhesive interaction. ${ }^{66}$

\section{INHIBITORS OF MONOCYTE ADHESION}

The interactions of lipids, endothelial cells, and monocytes in initiating the atherosclerotic process has led to the search for inhibitors of monocyte-endothelial cell adhesion. As mentioned above, certain phosphorylated disaccharides (lactose-1-phosphate and maltose-1-phosphate) have been shown to inhibit monocytic cell adhesion to activated endothelium in vitro. ${ }^{13}$ The same group demonstrated that octyl glucoside inhibited this interaction by acting on the monocyte rather than the endothelial cells. Numerous other investigators have shown that putative inhibitors of protein kinase $\mathrm{C}$, such as $\mathrm{H}-7$ and staurosporine, were able to inhibit the cytokine-stimulated expression of adhesion molecules by endothelial cells and their ability to bind monocytes. ${ }^{5567-70}$ These drugs may, however, be exerting their effects by acting through means other than the inhibition of protein kinase $\mathrm{C}$.

Wheeler and coworkers found that endothelial cells stimulated with IL-1, TNF $a$, or LPS secreted a leucocyte adhesion inhibitor that significantly decreased monocyte and neutrophil adhesion to activated endothelium. This inhibitor was subsequently shown to be an endothelial form of IL-8. ${ }^{71} 72$ Another cytokine, IL-4, was shown to inhibit monocyte adhesion to endothelial cells. ${ }^{73}$ This illustrates the complexity of the interaction between these cells, where some cytokines stimulate adhesion whereas others are able to inhibit the phenomenon, either directly or by the induction of other inhibitory molecules.

Because atherosclerosis has long been viewed as a chronic inflammatory process involving interactions between immunecompetent cells and components of the vessel wall, several anti-inflammatory compounds have been tested for their ability to inhibit leucocyte-endothelial cell binding. Hagihara and coworkers showed that dexamethasone and a lipoxygenase inhibitor FR 110302, but not the cyclooxygenase inhibitor indomethacin, inhibited cuff-induced monocyte adhesion to rabbit carotid arteries. ${ }^{74}$ The treatment of endothelial cells with benoxaprofen, a non-steroidal anti-inflammatory drug, had no effect on monocyte adhesion; conversely, however, pretreatment of monocytes for two hours caused a decrease in their ability to adhere to the endothelium. ${ }^{75}$ 3-Deazaadenosine, another anti-inflammatory compound, has been shown to decrease ICAM-1 mRNA levels and surface expression in TNF-treated endothelial cells. ${ }^{76}$ More recently Shankar et al also showed the ability of this drug to block agonist-induced monocyte adhesion to cultured human aortic endothelial cells. ${ }^{77}$

In view of the fact that oxidatively modified LDL and peroxidative stress can increase endothelial cell-monocyte adhesion, ${ }^{4478}$ antioxidants have been tested for their ability to mitigate this response. The studies to date in various model systems show mixed results. Shankar et al reported no decrease in monocyte adhesion in rats fed a high cholesterol diet supplemented with probucol, a lipid soluble antioxidant. ${ }^{79}$ Faruqi and DiCorleto, however, showed that probucol decreases agonist-induced monocytic cell adhesion to cultured endothelial cells (manuscript in preparation) and that $a$-tocopherol, another lipid-soluble antioxidant, decreased agonistinduced monocyte adhesion, E-selectin surface expression, and E-selectin mRNA concentrations. ${ }^{80}$ Recently, nitric oxide, also known as endothelial-derived relaxation factor, has also been shown to inhibit monocyte adhesion to endothelial cells. ${ }^{81}$ 


\section{Chemotaxis and diapedesis of monocytes}

It is now well established that the bloodborne monocyte is involved in the development of the atherosclerotic lesion. Attraction and adhesion of the monocyte to lesion-prone areas is central to this process. In the previous sections we discussed how endothelial/leucocyte adhesion molecules play a part in this process. In this section we concentrate on the chemotactic factors produced by the major cellular components of the atherosclerotic lesion (that is, the monocyte/macrophage, endothelial cell and smooth muscle cell) and how these factors might affect the localisation and transmigration of blood monocytes into atherosclerotic lesion areas.

Endothelial cells, when injured or activated, are capable of producing several chemoattractants, which if secreted into the intima would act to draw the bloodborne monocytes into the vessel wall. ${ }^{82}$ Pawlowski and coworkers showed in culture that monocytes selectively transmigrate via endothelial cell junctions. ${ }^{83}$ Schwartz et al were among the first to show that monocytic migration into the subendothelial space via cell junctions, may be occurring in response to chemoattractants present in the intima or media of the vessel wall. ${ }^{5}$ Others showed that aortic tissue extracts from hypercholesterolaemic swine were chemotactic for monocytes and that the control of monocyte recruitment into the lesion was dependent on changes in both the vascular wall components and functional alterations of the monocytes. ${ }^{84}$ Similar results have been found in a pigeon model of atherosclerosis. ${ }^{85}$ In another study, baboon smooth muscle cells were shown to produce a protein, smooth muscle cell chemotactic factor (SMC-CF), that is a chemoattractant for blood monocytes. ${ }^{86}$ Salvemini et al subsequently showed that SMC-CF is in fact monocyte chemotactic peptide (MCP-1) ${ }^{87}$

STIMULATORS AND INHIBITORS OF MONOCYTE CHEMOTAXIS

The relation between hypercholesterolaemia and atherosclerosis has generated much interest in the effects of various lipoproteins on monocyte chemotaxis. Monocytes purified from the blood of hypercholesterolaemic patients were shown to be more sensitive to chemoattractants than monocytes from controls, ${ }^{43}$ thus indicating that these bloodborne cells exhibit functional differences owing to their exposure to hyperlipidaemia. Quinn and coworkers have done much pioneering work in defining the role of oxLDL in monocyte chemotaxis. They showed that oxLDL was chemotactic for monocytes because of the presence of lysophosphatidylcholine (lysoPC). This lipid was found to be highly chemotactic to blood monocytes, while being inhibitory to the motility of resident macrophage ${ }^{88-90}$; thus it would serve to promote entry and reduce egress of the monocyte/macrophage, leading to their accumulation in the lesion. Berliner and colleagues found that $\mathrm{mm}-\mathrm{LDL}$ treatment of endothelial cells caused secretion of a monocyte chemoattractant. ${ }^{47}$ Smooth muscle cells have also been shown to secrete MCP-1 in response to mm-LDL. ${ }^{91}$ Hence, both vessel wall cell types seem capable of producing chemoattractants in response to lipoproteins. $\beta$ Migrating very low density lipoproteins $(\beta$ VLDL), though not chemotactic themselves, have been shown to stimulate large vessel endothelial cells to secrete a chemotactic peptide. ${ }^{92}$ In a conflicting study, Parthasarathy and coworkers reported that $\beta$-VLDL was in fact chemotactic for monocytes and contained a significant amount of lyso-PC. ${ }^{93}$

Monocyte chemotaxis and diapedesis has been studied in in vitro co-culture systems. Navab and coworkers showed that cocultures of endothelial cells and SMC (simulating the vessel wall) show increased MCP-1 secretion and monocyte transmigration when exposed to LDL. ${ }^{94}$ This effect was not seen when either cell was incubated independently with LDL, indicating that cell-cell interactions were necessary for MCP-1 induction. High density lipoprotein (HDL) was shown to inhibit monocyte transmigration. Furthermore, antioxidant pretreatment of co-cultures decreased the transmigration induced by $\mathrm{LDL}$, indicating that oxidation of the LDL was necessary in mediating the induction of chemotactic activity.

MCP-1 seems to be the major chemotactic molecule generated in the vessel wall and has received much attention recently. The MCP-1 gene is conserved in several primates and is thought to be the human homologue of the mouse JE gene. ${ }^{95}$ Several cytokines, such as IL-1, TNF, IFN $\gamma$, and GM-CSF; macrophage colony stimulating factor, as well as LPS and phytohaemagglutinin, have been shown to activate MCP-1 gene transcription in monocytes. ${ }^{9596}$ Endothelial cells and SMC also secrete MCP in response to stimulation with IL-1, TNF, and LPS. ${ }^{97}$ MCP-1 therefore is secreted by all three cell types in atherosclerotic lesions. Besides secreting MCP-1, monocytes also express high affinity receptors for MCP-1.98 This therefore sets the stage for the initiation and amplification of the monocyte recruitment process.

Multiple factors in addition to MCP-1 may also play a part in stimulating monocyte chemotaxis in the vessel wall. Besides stimulating the production of chemotactic factors by different cell types, cytokines such as TNF $a$ and lymphotoxin (TNF $\beta$ ), have themselves been shown to be chemotactic for monocytes. ${ }^{99-100}$ Furthermore, TNF has been shown to induce GM-CSF in endothelial cells, ${ }^{101}$ a molecule implicated in mediating adhesion and chemotaxis of monocytes. ${ }^{62102103}$ Leukotriene $B_{4}$, a product of the arachidonic acid-lipoxygenase pathway, FMLP (a bacterial product used as the reference standard for the assay of chemotactic activity), and zymosan-treated human serum, containing complement fragments, have all been shown to be chemotactic for monocytes. ${ }^{104} 105$ Published reports have suggested that serum derived complement

\section{.} . 
fragment $\mathrm{C} 5 \mathrm{a}$ and its product after carboxypeptidase treatment, $\mathrm{C} 5 \mathrm{a}_{\text {des-arg }}$, may play a part in vivo in attracting monocytes. ${ }^{106} 107 \mathrm{In}$ addition, $a$-thrombin, a coagulation cascade protease, has been demonstrated to be a potent chemoattractant for monocytes. ${ }^{108}$

Vessel wall components and growth factors have been implicated in inducing monocyte chemotaxis. Norris and coworkers showed that fibronectin fragments, which can be generated in the vessel wall matrix, were chemotactic for monocytes. ${ }^{109}$ Recently, advanced glycosylation end products (AGE), molecules known to accumulate in the vessel wall of patients with diabetes have also been shown to exhibit chemotactic activity for monocytes (a cell type with AGE specific receptors). ${ }^{110}$ The same group also demonstrated that monocyte interaction with AGE induced platelet-derived growth factor (PDGF) production by the monocytes. ${ }^{110}$ PDGF has itself been reported to be chemotactic for monocytes, but this subject remains controversial because others have found this not to be the case. ${ }^{11112}$ Another growth factor found to be chemotactic for monocytes is transforming growth factor- $\beta$ (TGF- $\beta$ ). ${ }^{113}$ In the same study monocytes were found to express high affinity receptors for TGF- $\beta$ on their surface and the interaction of TGF- $\beta$ with its receptor caused the induction of IL-1 gene expression in the monocyte. ${ }^{113}$ IL-1 production could in turn cause the secretion of other chemoattractants from surrounding cells in an autocrine and paracrine fashion, setting up a positive feedback cycle for the additional recruitment of monocytes.

In addition to generating chemoattractants, activated endothelial cells also produce inhibitors of monocyte recruitment. Wang and coworkers reported that IL-1-stimulated endothelial cells produced a protein, antigenically similar to a mouse retroviral protein, p15E, that inhibited monocyte chemotaxis. ${ }^{114}$ Nitric oxide and prostacyclin, potent vasodilators produced by endothelial cells, also inhibited FMLP-induced chemotaxis in monocytes. ${ }^{81}$ Fish oil has received much attention as an anti-atherogenic agent. Blood monocytes from people on diets supplemented with fish oil were less responsive to FMLP-induced chemotaxis. ${ }^{115116}$ This may be one mechanism by which fish oil acts to reduce cardiovascular disease.

Recent studies from several laboratories have indicated that leucocyte-endothelial cell adhesion proteins are involved not only in the initial binding of monocytes to endothelial cells but also in the transmigration of these leucocytes into the vessel wall. Hakkert and coworkers showed that monocyte transmigration seemed to be CD18 mediated; antibodies to E-selectin and VLA-4 reduced adhesion to endothelial cells but had no effect on monocyte migration. ${ }^{117}$ Well established chemoattractants were shown to induce monocytes to express the $\beta_{2}$ integrin counterreceptors, p150,95 and Mac-1 on their surface. ${ }^{35}$ This involved redistribution of these glycoproteins from intracellular granules to the surface, and did not require protein synthesis. Keizer and coworkers demonstrated that monocyte chemotaxis and chemokinesis were p150,95-dependent. ${ }^{37}$ Hence it seems that monocyte adhesion and chemotaxis probably act in concert in the recruitment of blood monocytes into lesion-prone areas of large vessels.

Recently, Butcher has proposed a threestep model for the recruitment, attachment and transmigration of monocytes through the endothelium. ${ }^{118}$ The model involves an initial reversible attachment of circulating monocytes to the endothelium mediated by the lymphocyte-selectin (L-selectin) receptor (present on monocytes as well). This slows the monocyte down in flow conditions, causing it to "roll" on the endothelial surface and so allowing more prolonged contact between the two cells. Step two only occurs if the endothelial cell has been activated and is expressing chemoattractants. If so, the monocyte receptor will bind to the chemoattractant molecule, become activated, and express the counter-receptors (Mac-1) to the injury-induced receptors (ICAM-1) on the endothelial cell surface, allowing stable monocyte-endothelial cell receptor binding. Stable binding then allows monocyte transmigration into the subendothelial space to occur. If the monocyte does not encounter the chemoattractant from an activated endothelial cell its binding is reversed and it returns to the circulation. Butcher has also eloquently discussed how the myriad of adhesion receptors interact in different combinations to allow the specificity and diversity of leucocyte-endothelial cell interactions. ${ }^{118}$

\section{The monocyte/macrophage in the vessel wall}

The subendothelial transmigration of the blood monocyte leads to the accumulation of these cells in the intima. Once in the intima, the monocyte is exposed to a milieu of modified lipoproteins, cytokines, chemoattractants, and growth factors, all of which can cause its activation and differentiation into a macrophage. When activated, the macrophage expresses several biologically active molecules such as cytokines, growth factors, and free radicals, which in turn modulate the activity of surrounding cells ${ }^{119}$ Some of these secretory products may serve as chemoattractants for the further recruitment of monocytes from the circulation (setting up an amplification system), as well as for vascular smooth muscle cells from the tunica media. The progression of the atherosclerotic lesion is dependent on the balance between the positive and negative feedback loops generated by its cellular components. The free radicals generated by the macrophage not only act on the cellular components of the lesion but can also further modify the LDL present in the intima.

Besides being a secretory cell, the macrophage is also an active phagocyte. The scavenger receptor implicated in the ingestion of modified $\mathrm{LDL}^{120}$ is expressed on its sur- 
face. The lipid-laden macrophage seen in early lesions (fatty streaks) has been termed a "foam cell" because of its morphological appearance. Several groups have shown the transformation of the macrophage into a foam cell after lipid ingestion. ${ }^{1346710}$ This process is discussed in detail elsewhere in this supplement.

The proliferative nature of the atherosclerotic lesion has been known for several decades, and now the development of more sophisticated investigative techniques has allowed us to discern the individual cell types involved in the proliferative response. Until recently it was thought that the macrophage was a terminally differentiated cell, not capable of proliferative activity. Though several decades ago foam cells were shown to incorporate ${ }^{3} \mathrm{H}$-thymidine into DNA, they were thought to originate from phenotypically modified smooth muscle cells. ${ }^{121} 122$ The development of more specific cell markers and monoclonal antibodies against the proliferating cell nuclear antigen (PCNA or cyclin) has allowed the re-examination of the identity of these cells. Rosenfeld and Ross, using ${ }^{3} \mathrm{H}$-thymidine incorporation and monoclonal antibodies in a rabbit model, showed that approximately $30 \%$ of the proliferative cells in lesion areas were macrophages. ${ }^{123}$ Furthermore, an inverse relation between the thymidine labelling index and lesion size was seen, suggesting that earlier atherosclerotic lesions were more proliferative. Using monoclonal antibodies against different cell types and PCNA (a more sensitive marker of proliferation than ${ }^{3} \mathrm{H}$-thymidine incorporation), Gordon and coworkers showed that whereas the rates of cell proliferation were low in human coronary artery atherosclerotic plaques (in keeping with a lesion that develops over years), $27 \cdot 1 \%$ of PCNA positive cells were macrophages and $15.5 \%$ were smooth muscle cells. ${ }^{124}$ Evidently, the macrophage continues to proliferate in the intima, contributing to the growth of the lesion.

The corpulent foam cell tends to stay in the lesion area, possibly because its motility is inhibited by lyso-PC. ${ }^{89}$ Evidence from studies on hypercholesterolaemic swine indicate that occasionally the lipid-laden foam cells do re-enter the circulation. ${ }^{7}$ Gerrity hypothesised that egress occurred throughout the development of the lesion. He proposed that foam cells from early lesions returned to the circulation without endothelial damage; whereas, foam cells from later lesions, being more lipid-laden and larger, damaged the endothelium during their egress. ${ }^{7} \mathrm{He}$ also suggested that the progression of the lesion was determined by the balance between monocyte immigration into the lesion and foam cell emigration into the circulation. Foam cell egress was also seen in a primate model of diet-induced atherosclerosis. ${ }^{34}$ The most dramatic increase in circulating foam cells in this model occurred after four months on a high cholesterol diet. Not much is known about the final fate of the foam cells that re-enter the circulation. Gerrity was able to demonstrate necrotic foam cells in the liver and spleen of the hypercholesterolaemic swine. $^{7}$

\section{Conclusion}

$\underline{\underline{m}}$

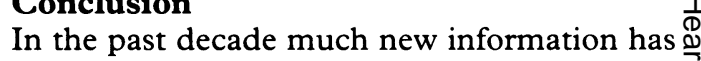
accrued regarding the molecular and cellular $\stackrel{c}{c}$ events leading to monocyte infiltration and accumulation in the vessel wall. Despite this $\stackrel{\vec{P}}{+}$ flurry of research activity many questions? remain unanswered. First, it is unclear why 흠 specific regions of the vasculature exhibit $\frac{\bar{\phi}}{\nabla}$ focal adhesion of monocytes during early $\stackrel{\Phi}{2}$ diet-induced atherosclerosis. Secondly, as yet क the molecular reasons for leucocyte specificity $\overrightarrow{0}$ are also unknown. Why is it that neutrophils do not participate in the atherogenic process $\vec{\omega}$ though many other features of plaque development are analogous to an inflammatory response? Thirdly, the fate of most of the monocytes that enter the lesion remains ${ }^{\infty} \infty$ unknown. The fraction of foam cells that re- $\frac{c}{0}$ enter the circulation, causing endothelial cell 으 damage, still needs to be defined. Finally, the $s$ recent recognition of proliferation of mono- 6

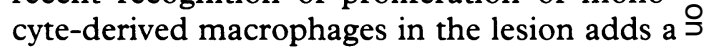
new twist to the question of intimal prolifera- $\vec{c}$ tion, formerly thought to be strictly a smooth muscle cell phenomenon. The question as to whether specific macrophage subpopulations are involved in this proliferative response, and $\vec{\theta}$ what their precise role in the atherogenic process might be, are areas that need further study. As new molecular probes are developed many of these questions should be resolved.

We thank Carol de la Motte and Earl Poptic for their scientific input and Susan Cothren for her clerical assistance. scientific input and Susan Cothren for her clerical assistance.

Ross R. The pathogenesis of atherosclerosis-an update. $\vec{\nabla}$ New Engl F Med 1986;314:488-500.

2 Joris I, Zand T, Nunnari JJ, Krolikowski FJ, Majno G. Studies on the pathogenesis of atherosclerosis. I. Adhesion and emigration of mononuclear cells in the aorta of hypercholesterolemic rats. $A m$ f Pathol 1983;113:341-58

3 Faggiotto A, Ross R, Harker L. Studies of hypercholesterolemia in the nonhuman primate. I. Changes that lead to fatty streak formation. Arteriosclerosis 1984; 4:323-40.

4 Faggiotto A, Ross. R. Studies of hypercholesterolemia in the nonhuman primate. II. Fatty streak conversion to

5 Schwartz CJ, Sprague EA, Kelley JL, Valente AJ,

Suenram CA. Aortic intimal monocyte recruitment in $N$ the normo and hypercholesterolemic baboon (Papio cynocephalus). An ultrastructural study: Implications in $\mathrm{C}$ atherogenesis. Virchows Arch [A] 1985;405:175-91

6 Gerrity RG. The role of monocyte in atherogenesis. I. Transition of blood-borne monocytes into foam cells inco fatty lesions. Am F Pathol 1981;103:181-90.

7 Gerrity RG. The role of the monocyte in atherogenesis. II. Migration of foam cells from atherosclerotic lesions.? Am F Pathol 1981;103:191-200.

8 Taylor RG, Lewis JC. Endothelial cell proliferation and monocyte adhesion to atherosclerotic lesions of white $\overrightarrow{\mathbb{D}}$ carneau pigeons. Am $\mathcal{F}$ Pathol 1986;125:152-60.

9 Aqel NM, Ball RY, Waldmann H, Mitchinson MJ. Identification of macrophages and smooth muscle cells in human atherosclerosis using monoclonal antibodies in human atherosclerosis usin
f Pathol 1985;146:197-204.

10 Klurfeld DM. Identification of foam cells in human atherosclerotic lesions as macrophages using monoclonalo antibodies. Arch Pathol Lab Med 1985;109:445-9.

11 Jonasson L, Holm J, Skalli O, Bondjer G, Hansson GK.ㅡ Regional accumulations of $T$ cells, macrophages, and? smooth muscle cells in the human atherosclerotic plaque. Arteriosclerosis 1986;6:131-8.

12 Bevilacqua MP, Stengelin S, Gimbrone MA Jr, Seed B Endothelial leucocyte adhesion molecule 1: An inducible receptor for neutrophils related to complement regulatory proteins and lectins. Science 1989;243:1160-5. 
13 DiCorleto PE, de la Motte CA. Role of cell surface carbohydrate moieties in monocytic cell adhesion to endothelium in vitro. $\mathcal{F}$ Immunol 1989;143:3666-72.

14 Pigott R, Needham LA, Edwards RM, Walker C, Power C. Structural and functional studies of the endothelial activation antigen endothelial leucocyte adhesion molecule-1 using a panel of monoclonal antibodies. Immunol 1991;147:130-5.

15 Phillips ML, Nudelman E, Gaeta FCA, Perez M Singhal AK, Hakomori S-I, et al. ELAM-1 mediates cel adhesion by recognition of a carbohydrate ligand, SialylLex. Science 1990;250:1130-2.

16 Walz G, Aruffo A, Kolanus W, Bevilacqua M, Seed B. Recognition by ELAM-1 of the Sialyl-Le ${ }^{x}$ determinan on myeloid and tumour cells. Science 1990;250:1132-4.

17 Lowe JB, Stoolman LM, Nair RP, Larsen RD, Berhend TL, Marks RM. ELAM-1-dependent cell adhesion to vascular endothelium determined by a transfected
human fucosyltransferase cDNA. Cell 1990;63:475-84.

18 Carlos T, Kovach N, Schwartz B, Rosa M, Newman B, Wayner $\mathrm{E}$, et al. Human monocytes bind to two cytokine-induced adhesive ligands on cultured human endothelial cells: Endothelial-leucocyte adhesion molecule- 1 and vascular cell adhesion molecule-1. Blood 1991;77:2266-71.

19 Leeuwenberg JFM, Jeunhomme TMAA, Buurman WA Role of ELAM-1 in adhesion of monocytes to activated human endothelial cells. Scand 7 Immunol 1992;35: $335-41$

20 McEver RP, Martin MN. A monoclonal antibody to a membrane glycoprotein binds only to activated platelets. F Biol Chem 1984;259:9799-804.

21 Hsu-Lin S-C, Berman CL, Furie BC, August D, Furie B. A platelet membrane protein expressed during platelet activation and secretion. I Biol Chem 1984 259:9121-6.

22 Bonfanti $R$, Furie BC, Furie B, Wagner DD. PADGEM (GMP140) is a component of Weibel-Palade bodies of human endothelial cells. Blood 1989;73:1109-12.

23 Hattori R, Hamilton KK, Fugate RD, McEver RP, Sims PJ. Stimulated secretion of endothelial von Willebrand factor is accompanied by rapid redistribution to the cell surface of the intracellular granule membrane protein surface of the intracellular granule mem

24 Yeo E, Furie BC, Furie B. PADGEM protein in human erythroleukemia cells. Blood 1989;73:722-8.

25 Larsen E, Palabrica T, Sajer S, Gilbert GE, Wagner DD, Furie BC, et al. PADGEM-dependent adhesion of platelets to monocytes and neutrophils is mediated by lineage-specific carbohydrate, LNF III (CD15). Cell 1990;63:467-74.

26 Cybulsky MI, Gimbrone MA Jr. Endothelial expression of a mononuclear leucocyte adhesion molecule during atherogenesis. Science 1991;251:788-91.

27 Osborn L, Hession C, Tizard R, Vassallo C, Luhowskyl $\mathrm{S}$, Chi-Rosso G, et al. Direct expression cloning of vascular cell adhesion molecule 1 , a cytokine-induced vascular cell adhesion molecule 1 , a cytokine-induced 1989;59:1203-11.

28 Cybulsky MI, Fries JWU, Williams AJ, Sultan P, Davis $\mathrm{VM}$, Gimbrone MA Jr, et al. Alternative splicing of human VCAM-1 in activated vascular endothelium Am $\mathcal{F}$ Pathol 1991;138:815-20.

29 Simmons DL, Needham L. Cloning cell surface molecules using monoclonal antibodies. In: Gordon $\mathrm{JL}$, ed. Vascular endothelium: Interactions with circulating cells. London: Elsevier Science Publishers 1991;3-29.

30 Elices MJ, Osborn L, Takada Y, Crouse C, Luhowskyj $S$, Hemler ME, et al. VCAM-1 on activated endothelium interacts with the leucocyte integrin VLA-4 at a site
distinct from the VLA-4/fibronectin binding site. Cell distinct from the

31 Jonjic N, Jilek P, Bernasconi S, Peri G, Martin-Padura I Cenzuales S, et al. Molecules involved in the adhesion and cytotoxicity of activated monocytes on endothelia cells. F Immunol 1992;148:2080-3.

32 Staunton DE, Marlin SD, Stratowa C, Dustin ML Springer TA. Primary structure of ICAM-1 demonstrates interaction between members of the immunoglobulin and integrin supergene families. Cell 1988 ; 52:925-33.

33 Staunton DE, Dustin ML, Springer TA. Functional cloning of ICAM-2, a cell adhesion ligand for LFA-1 cloning of ICAM-2, a cell adhesion ligand for

34 Marlin SD, Springer TA. Purified intercellular adhesion molecule-1 (ICAM-1) is a ligand for lymphocyte function-associated antigen 1 (LFA-1). Cell 1987;51;813-9.

35 Miller LJ, Bainton DF, Borregaard N, Springer TA Stimulated mobilization of monocyte Mac-1 and p150,95 adhesion proteins from an intracellula vesicular compartment to the cell surface. $\mathcal{f}$ Clin Inves 1987;80:535-44

36 Te Velde AA, Keizer GD, Figdor CG. Differential function of LFA-1 family molecules (CD11 and CD18) in adhesion of human monocytes to melanoma and endothelial cells. Immunology 1987;61:261-7.

37 Keizer GD, Te Velde AA, Schwarting R, Figdor CG, De Vries JE. Role of p150,95 in adhesion, migration, chemotaxis and phagocytosis of human monocytes. Eur chemotaxis and phagocytosis

38 Dustin ML, Springer TA. T-cell receptor cross-linking transiently stimulates adhesiveness through LFA-1. Nature 1989;341:619-24. 39 Springer TA. Adhesion receptors of the immune system
40 Nortamo P, Li R, Renkonen R, Timonen T, Prieto J, Patarroyo $M$, et al. The expression of human intercellular adhesion molecule-2 is refractory to inflammatory cytokines. Eur f Immunol 1991;21:2629-32.

41 Poston RN, Haskard DO, Coucher JR, Gall NP, Johnson-Tidey RR. Expression of intercellular adhesion molecule- 1 in atherosclerotic plaques. Am $\mathcal{f}$ Pathol 1992;140:665-73.

42 Printseva OY, Peclo MM, Gown AM. Various cell types in human atherosclerotic lesions express ICAM-1. Am $\mathcal{F}$ Pathol 1992;140:889-96.

43 Bath PM, Gladwin AM, Martin JF. Human monocyte characteristics are altered in hypercholesterolaemia. Atherosclerosis 1991;90:175-81.

44 Parthasarathy S, Steinberg D, Witzum JL. The role of oxidized low-density lipoproteins in the pathogenesis of atherosclerosis. Annu Rev Med 1992;43:219-25.

45 Frostegard J, Nilsson J, Haegerstrand A, Hamsten A Wigzell $\mathrm{H}$, Gidlund M. Oxidized low density lipoprotein induces differentiation and adhesion of human tein induces differentiation and adhesion of human monocytes and the monocytic

46 Pritchard KA Jr, Tota RR, Lin JH-C, Danishefsky KJ, Kurilla BA, Holland JA, et al. Native low density lipoprotein. Endothelial cell recruitment of mononuceriosclerosis Thrombosis 1991;11:1175-81.

47 Berliner JA, Territo MC, Sevanian A, Ramin S, Kim JA Bamshad B, et al. Minimally modified low density lipoprotein stimulates monocyte endothelial interactions. F Clin Invest 1990;85:1260-6.

48 Territo MC, Berliner JBA, Almada L, Ramirez $R$ Fogelman AM. $\beta$-very low density lipoprotein pretreatment of endothelial monolayers increases monocyte adhesion. Arteriosclerosis 1989;9:824-8.

49 Endemann G, Pronzcuk A, Friedman G, Lindsey S Alderson L, Hayes KC. Monocyte adherence to
endothelial cells in vitro is increased by $\beta$-VLDL. $A m \mathcal{F}$ Pathol 1987;126:1-6.

50 Foxall TL, Shwaery GT. Effects of dietary fish oil and butterfat on serum lipids and monocyte and platelet interactions with aortic endothelial cells. Atherosclerosis 1990;80:171-9.

51 Kim DN, Schmee J, Lee CS, Eastman A, Ross JS, Thomas WA. Comparison of effects of fish oil and corn oil supplements on hyperlipidemic diet induced atherogenesis in swine. Atherosclerosis 1991;89:191-201.

52 Bevilacqua MP, Pober JS, Wheeler ME, Cotran RS Gimbrone MA Jr. Interleukin 1 acts on cultured human vascular endothelium to increase the adhesion of polymorphonuclear leukocytes, monocytes, and related leukocyte cell lines. 7 Clin Invest 1985;76:2003-11.

53 Bevilacqua MP, Pober JS, Wheeler ME, Cotran RS, Gimbrone MA Jr. Interleukin-1 activation of vascular endothelium. Effects on procoagulant activity and leucocyte adhesion. Am f Pathol 1985;121:393-403.

54 Bevilacqua MP, Pober JS, Mendrick DL, Cotran RS, Gimbrone MA Jr. Identification of an inducible Gimbrone MA Jr. Identification of an inducible Sci USA 1987;84:9238-42.

55 Pober JS, Gimbrone MA Jr, Lapierre LA, Mendrick DL Fiers, W, Rothlein $\mathrm{R}$, et al. Overlapping patterns of activation of human endothelial cells by interleukin 1 , tumor necrosis factor, and immune interferon. Immunol 1986;137:1893-6.

56 Dustin ML, Rothlein R, Bhan AK, Dinarello CA Springer TA. Induction by IL 1 and interfereon- $\gamma$ : Tissue distribution, biochemistry, and function of a natural adherence molecule (ICAM-1). $f$ Immunol 1986; 137:245-54.

57 Di Corleto PE, de la Motte CA. Thrombin cause increased monocytic-cell adhesion to endothelial cells through a protein kinase $\mathrm{C}$-dependent pathway. through a protein kin
Biochem $\mathcal{1}$ 1989;264:71-7.

58 Span AH, Endert J, Van Boven CP, Bruggeman CA Virus induced adherence of monocytes to endothelial cells. FEMS Microbiol Immunol 1989;1:237-44.

59 Span AH, van Dam-Mieras MC, Mullers W, Endert J Muller AD, Bruggeman CA. The effect of virus infection on the adherence of leucocytes or platelets to endothelial cells. Eur 7 Clin Invest 1991;21:331-8.

60 Etingin OR, Silverstein RL, Hajjar DP. Identification of a monocyte receptor on herpes virus-infected endothelial cells. Proc Natl Acad Sci USA 1991;88:7200-3.

61 Fabricant CG. Herpes virus-induced atherosclerosis. In: Notkins AL, Oldstone MBA, eds. Concepts in viral pathins AL, Oldstone MBA, eds. Concepts in viral

62 Benditt EP, Barrett T, McDougall JK. Viruses in the etiology of atherosclerosis. Proc Natl Acad Sci USA 1983;80:6386-9.

63 Hajiar DP. Viral pathogenesis of atherosclerosis. Impact of molecular mimicry and viral genes. Am $\mathcal{f}$ Pathol 1991;139:1195-211.

64 Elliott MJ, Vadas MA, Cleland LG, Gamble JR, Lopez AF. IL-3 and granulocyte-macrophage colonystimulating factor stimulate two distinct phases of adhesion in human monocytes. F Immunol 1990;145:167-76.

65 Schleimer RP, Rutledge BK. Cultured human vascular endothelial cells acquire adhesiveness for neutrophils after stimulation with interleukin 1 , endotoxin, and tumor-promoting phorbol diesters. $\mathcal{F}$ Immunol 1986; 136:649-54.

66 Doherty DE, Haslet C, Tonnesen MG, Henson PM Human monocyte adherence: A primary effect of chemotactic factors on the monocyte to stimulate adherence to human endothelium. F Immunol 1987;138: 
1762-71

67 Myers CL, Desai SN, Schembri-King J, Letts GL Wallace RW. Discriminatory effects of protein kinase inhibitors and calcium ionophore on endothelial ICAM 1 induction. Am F Physiol 1992;262:C365-73.

68 Renkonen R, Mennander A, Ustinov J, Mattila P. Activation of protein kinase $C$ is crucial in the regulaActivation of protein kinase $C$ is crucial in the regula-
tion of ICAM-1 expression on endothelial cells by intertion of ICAM-1 expression on endothelial

69 Montgomery KF, Osborn L, Hession C, Tizard R, Gof $\mathrm{D}$, Vassallo C, et al. Activation of endothelial-leucocyte D, Vassallo C, et al. Activation of endothelial-leucocyte adhesion molecule 1 (ELAM-1) gen

70 Lane TA, Lamkin GE, Wancewicz EV. Protein kinase C inhibitors block the enhanced expression of intercellula adhesion molecule-1 on endothelial cells activated by interleukin-1, lipopolysaccharide and tumor necrosis factor. Biochem Biophys Res Commun 1990;172:1273-81.

71 Wheeler ME, Luscinskas FW, Bevilacqua MP, Gimbrone MA Jr. Cultured human endothelial cells stimulated with cytokines or endotoxin produce an inhibitor of leucocyte adhesion. 7 Clin Invest 1988; 82:1211-8.

72 Gimbrone MA Jr, Obin MS, Brock AF, Luis EA, Hass PE, Hebert CA, et al. Endothelial interleukin-8: A nove inhibitor of leucocyte-endothelial interactions. Science 1989;246:1601-3.

73 Elliott MJ, Gamble JR, Park LS, Vadas MA, Lopez AF Inhibition of human monocyte adhesion by interleukin4. Blood 1991;77:2739-45.

74 Hagihara $\mathrm{H}$, Nomoto A, Mutoh S, Yamaguchi I, Ono T. Role of inflammatory responses in initiation of atherosclerosis: Effects of anti-inflammatory drugs on cuffinduced leucocyte accumulation and intimal thickening of rabbit carotid artery. Atherosclerosis 1991;91:107-16.

75 Brown KA, Ferrie J, Wilbourn B, Dumond DC. Benoxaprofen inhibits the adhesion of human mono-
cytes to cultured vascular endothelium. Agents Actions cytes to cultured

76 Jurgensen CH, Huber BE, Zimmerman TP, Wolberg G -deazaadenosine inhibits leucocyte adhesion and ICAM-1 biosynthesis in tumor necrosis factor-stimulated human endothelial cells. $\mathcal{F}$ Immunol 1990;144 653-61

77 Shankar R, de la Motte CA, DiCorleto PE. 3-deazaadenosine inhibits thrombin-stimulated platelet-derived growth factor production and endothelial-leucocyte adhesion molecule-1-mediated monocytic cell adhesion in human aortic endothelial cells. F Biol Chem 1992; 267:9376-82.

78 Molenaar R, Visser WJ, Verkerk A, Koster JF, Jongkind JF. Peroxidative stress and in vitro ageing of endothelia cells increases the monocyte-endothelial cell adherence in a human in vitro system. Atherosclerosis 1989;76 193-202.

79 Shankar R, Sallis JD, Stanton H, Thomson R. Influence of probucol on early experimental atherogenesis in hypercholesterolemic rats. Atherosclerosis 1989;78:91-7.

80 Faruqi RM, DiCorleto PE. Inhibition of monocyte adhesion to human umbilical vein endothelial cells (EC) by a-tocopherol (a-tcp). FASEB f 1992;6:A1592.

81 Bath PM, Hassal DG, Gladwin AM, Palmer RM Martin JF. Nitric oxide and prostacyclin. Divergence of Martin JF. Nitric oxide and prostacyclin. Divergence of inhibitory effects on monocyte chemotaxis and adhesion to endothelium

82 Oppenheim JJ, Zachariae COC, Mukaida N, Matsushima K. Properties of the novel proinflammatory supergene "intercrine" cytokine family. Annu Rev Immunol 1991;9:617-48.

83 Pawlowski NA, Kaplan G, Abraham E, Cohn ZA. The selective binding and transmigration of monocytes through the junctional complexes of human endothelium. F Exp Med 1988;168:1865-82.

84 Gerrity RG, Goss JA, Soby L. Control of monocyte recruitment by chemotactic factor(s) in lesion-prone recruitment by chemotactic factor(s) in lesion-pr

85 Denholm EM. Monocyte chemoattractants in pigeon aortic atherosclerosis. Am $\mathcal{F}$ Pathol 1987;126:464-75.

86 Valente AJ, Fowler SR, Sprague EA, Kelley JL, Suenram CA, Schwartz CJ. Initial characterisation of a peripheral blood mononuclear cell chemoattractant derived from cultured arterial smooth muscle cells. Am $\mathcal{f}$ Pathol 1984;117:409-17

87 Salvemini D, deNucci G, Gryglewski RJ. Monocyte chemotactic protein 1 in human endothelial cells and smooth muscle cells. Proc Natl Acad Sci USA 1990 87:5134-8.

88 Quinn MT, Parthasarathy S, Fong LG, Steinberg D. Oxidatively modified low density lipoproteins: A potential role in recruitment and retention of monopotential role in recruitment and retention of monoSci USA 1987;84:2995-8.

89 Quinn MT, Parthasarathy S, Steinberg D. Endothelial cell-derived chemotactic activity for mouse peritoneal macrophages and the effects of modified forms of low density lipoprotein. Proc Natl Acad Sci USA 1985, 82:5949-53.

90 Quinn MT, Parthasarathy S, Steinberg D. Lysophosphatidylcholine: A chemotactic factor for human monocytes and its potential role in atherogenesis. Proc Natl Acad Sci USA 1988;85:2805-9.

91 Cushing SD, Berliner JA, Valente AJ, Territo MC, Navab M, Parhami F, et al. Minimally modified low density lipoprotein induces monocyte chemotactic pro- tein 1 in human endothelial cells and smooth muscle cells. Proc Natl Acad Sci USA 1990;87:5134-8.

92 Berliner JA, Territo M, Almada L, Carter A, Shafonsky E, Fogelman AM. Monocyte chemotactic factor produced by large vessel endothelial cells in vitro. 0 Arteriosclerosis 1986;6:254-8.

93 Parathasarathy S, Quinn MT, Schwenke DC, Carew T TE, Steinberg D. Oxidative modification of $\beta$-very low density lipoprotein. Potential role in monocyte recruitment and foam cell formation. Arteriosclerosis 1989; $\mathrm{C}$ 9:398-404

94 Navab M, Imes SS, Hama SY, Hough GP, Ross LA, $\overrightarrow{\bar{F}}$ Bork RW, et al. Monocyte transmigration induced by modification of low density lipoprotein in cocultures of human aortic wall cells is due to induction of monocyte $\frac{-}{O}$ chemotactic protein 1 synthesis and is abolished by high $\frac{\bar{\sigma}}{\bar{\omega}}$ density lipoprotein. 7 Clin Invest 1991;88:2039-46.

95 Moore SK, Appella E, Lerman MI, Leonard EJ. Human monocyte chemoattractant protein-1 (MCP1). Full- 0 length cDNA cloning, expression in mitogen-stimulated blood mononuclear leucocytes, and sequence similarity $\backsim$ to mouse competence gene JE. FEBS Letts 1989; $\overrightarrow{0}$ 244:487-93.

96 Colotta F, Borre A, Wang JM, Tattanelli M, Maddalena $\overrightarrow{\vec{\omega}}$ $\mathrm{F}$, Polentarutti $\mathrm{N}$, et al. Expression of a monocyte $\vec{\omega}$ chemotactic cytokine by human mononuclear phagocytes. F Immunol 1992;148:760-5.

97 Wang JM, Sica A, Giuseppe P, Walter S, Padura IM, Libby $\mathrm{P}$, et al. Expression of monocyte chemotactic pro- 6 tein and interleukin- 8 by cytokine-activated human vas- cular smooth muscle cells. Arteriosclerosis Thrombosis 1991;11:1166-74.

98 Yoshimura T, Leonard EJ. Identification of high affinity receptors for human monocyte chemoatractant proteinreceptors for human monocyte chemoattractant protein-
1 on human monocytes. F Immunol 1990;145:292-7.

99 Ming WJ, Bersani L, Mantovani A. Tumor necrosis factor is chemotactic for monocytes and polymorphonuclear leucocytes. F Immunol 1987;138:1469-74.

100 Wang JM, Walter S, Mantovani A. Re-evaluation of the chemotatic activity of tumour necrosis factor for monocytes. Immunology 1990;71:364-7.

101 Munker R, Gasson J, Ogawa M, Koeffler HP. Recombinant human TNF induces production of granulocyte-monocyte colony-stimulating factor. Nature 1986;323:79-82.

102 Wang JM, Colella S, Allavena P, Mantovani A. Chemotactic activity of human recombinant granulocyte-macrophage

103 Wang JM, Chen ZG, Colotta F, Mantovani A. Role of GM-CSF in phagocyte recruitment and regulation of cfos protooncogene expression. Behring Inst Mitt 1988;83:270-3.

104 Darby H, Brown KA, Anderson RA, Williams BT, 응 Dumonde DC. Transendothelial chemotaxis in vitro of human monocytes. $f$ Immunol Methods 1988;113: 157-63.

105 Migliorisi G, Folkes E, Pawlowski N, Cramer EB. In vitro studies of human monocyte migration across vitro studies of human monocyte migration across f-Med-Leu-Phe. Am f Pathol 1987;127:157-67.

106 Snyderman R, Altman LC, Hausman MS, Mergenhagen SE. Human mononuclear leucocyte chemotaxis: A quantitative assay for humoral and cellular chemotactic factors. F Immunol 1972;108:857-60.

107 Marder SR, Chenoweth DE, Goldstein IM, Perez HD. 윽 Chemotactic responses of human peripheral blood monocytes to the complement-derived peptides $\mathrm{C} 5 \mathrm{a}$ O and C5a des Arg. F Immunol 1985;134:3325-31

108 Bar-Shavit R, Kahn A, Wilner GD, Fenton JW II Monocyte chemotaxis: stimulation by specific exosite 윽
region in thrombin. Science $1983 ; 220: 728-31$.

109 Norris DA, Clark RA, Swigart LM, Huff JC, Weston I WL, Howell SE. Fibronectin fragment(s) are chemotac-O tic for human peripheral blood monocytes. $\mathcal{f}$ Immunol 1982;129:1612-8.

110 Kirstein M, Brett J, Radoff S, Ogawa S, Stern D, S Vlassara $H$. Advanced protein glycosylation induces $N$ transendothelial human monocyte chemotaxis and $\mathrm{N}$ secretion of platelet-derived growth factor: role in vascu- $\omega$ lar disease of diabetes and ageing. Proc Natl Acad Scio USA 1990;87:9010-4

111 Deuel TF, Senior RM, Huang JS, Griffin GL.C Chemotaxis of monocytes and neutrophils to plateletderived growth factor. $\mathcal{F}$ Clin Invest 1982;69:1046-9.

112 Graves DT, Grotendorst GR, Antoniades HN, Schwartz CJ, Valente AJ. Platelet-derived growth factor is not chemotactic for human peripheral blood monocytes. Exp Cell Res 1989;180:497-503.

113 Wahl SM, Hunt DA, Wakefield LM, McCartney-Francis N, Wahl LM, Roberts AB, et al. Transforming growth factor type beta induces monocyte chemotaxis and factor type beta induces monocyte chemotaxis and growth factor prod

114 Wang JM, Chen ZG, Cianciolo GJ, Snyderman R, Breviario F, Dejana E, et al. Production of a retroviralo P15E-related chemotax inhibitor by IL-1-treated endothelial cells. F Immunol 1989;142:2012-7.

115 Schmidt EB, Pedersen JO. Ekelund S, Grunnet N, Jersild C, Dyerberg J. Cod liver oil inhibits neutrophi and monocyte chemotaxis in healthy males. Atherosclerosis $1989 ; 77: 53-7$

116 Schmidt EB, Pedersen JO, Varming K, Ernst E, Jersild C, Grunnet $\mathrm{N}$, et al. $\mathrm{n}-3$ fatty acids and leucocyte chemotaxis. Effects in hyperlipidemia and dose- 
response studies in healthy men Arteriosclerosis Thrombosis 1991;11:429-35.

117 Hakkert BC, Kuijpers TW, Leeuwenberg JFM, van Mourik JA, Roos D. Neutrophil and monocyte adherence to and migration across monolayers of cytokineactivated endothelial cells: The contribution of CD18, ELAM-1, and VLA-4. Blood 1991;78:2721-6.

118 Butcher EC. Leucocyte-endothelial cell recognition: Three (or more) steps to specificity and diversity. Cell 1991;67:1033-6.

119 Adams DO, Hamilton TA. Macrophages as destructive cells in host defense. In: Gallin JI, Goldstein IM, Snyderman $\mathrm{R}$, eds. Inflammation: Basic principles and clinical correlates, second edition. New York: Raven Press, clinical correla

120 Brown MS, Goldstein JL. Lipoprotein metabolism in the macrophage: implications for cholesterol deposition in atherosclerosis. Ann Rev Biochem 1983;52:223-61.

121 McMillan GC, Duff GL. Mitotic activity in the aortic lesions of experimental atherosclerosis in rabbits. Arch Pathol 1948;46:179-82.
Pesions of experimental

122 Benditt EP, Benditt JM. Evidence for a monoclonal origin of human atherosclerotic plaques. Proc Natl Acad Sci USA 1973;70:1753-6.

123 Rosenfeld ME, Ross R. Macrophage and smooth muscle cell proliferation in atherosclerotic lesions of WHHL and comparably hypercholesterolemic fat-fed rabbits. Arteriosclerosis 1990;10:680-7.

124 Gordon D, Reidy MA, Benditt EP, Schwartz SM. Cell proliferation in human coronary arteries. Proc Natl Acad Sci USA 1990;87:4600-4.

\section{ABSTRACTS IN CARDIOLOGY}

\section{Laboratory screening}

Laboratories that estimate plasma lipid concentrations serve two purposes. One function is to screen large numbers of symptom free individuals, the other to provide detailed lipid profiles on those who already have clinically expressed atherosclerosis. The survey of United Kingdom laboratories reported in the fournal of Clinical Pathology shows little evidence that the service provided is being tailored to these separate functions.

A pragmatic approach to symptom free individuals is the estimation of total serum cholesterol in the non-fasting state. The assumption that cholesterol concentrations less than $6.5 \mathrm{mmol} / \mathrm{l}$ are acceptable will miss few important atherogenic lipid abnormalities. Concentrations above $6.5 \mathrm{mmol} / 1$ and individuals with symptoms as defined above, require fasting samples and the additional measurement of triglyceride and HDL cholesterol. The survey, however, showed that half the laboratories still demanded fasting samples before undertaking any lipid analysis whatsoever.

The technical standard of the laboratories in estimating serum total cholesterol was high, though interlaboratory variation may still be too large. This reflects considerable diversity in calibration procedures. Many laboratories $(62 \%)$ continue to give gratuitous advice on the significance of the result. A reference range based on estimations of lipid concentrations in supposedly normal individuals is meaningless, given the high serum cholesterol concentration in United Kingdom populations and the prevalence of occult atherosclerotic disease. Giving a value above which there is a risk of ischaemic heart disease is arbitrary because the risk is a continuous variable.

The provision of more sophisticated lipid analysis including $L p(a)$ and apolipoproteins is far more variable, the quality of the analysis less controlled, and the clinical significance of any abnormality found in relation to treatment less certain.

Whatever the pros and cons of treating hyperlipidaemia in symptom free individuals by anything more than dietary advice, an increasing number of individuals wish to know their cholesterol concentration. This tendency will be accelerated by the over-thecounter testing kits that are now available. Their accuracy is not certain and they are not subject to formal quality assurance when used by the population at large.

Doctors requesting lipid analysis should make clear what level of sophistication they need to manage their patients clinically. Laboratories should be prepared to accommodate these needs.

MJ DAVIES

\section{Laboratory facilities for investigating lipid disorders in the United Kingdom: results of the British Hyperlipidaemia Association Survey}

\section{F Laker, I P D Reckless, D I Betteridge, PN Durrington, I P Mäller, D P Nicholls, I Shepherd,} $G R$ Thompson

\section{Abstract}

Aims.-To determine the availability of facilities for the investigation of hyperlipidaemia in the United Kingdom.

Methods-A questionnaire was sent to all health districts in the United Kingdom.

Results. - The response rate was $81 \%$. All laboratories used enzymatic techniques to measure serum triglyceride and cholesterol concentrations, although there were differences in standardisation procedures. Reference ranges for serum lipids were quoted by $58 \%$ of laboratories while $50 \%$ quoted "desirable limits". Almost half specified that fasting blood samples were required. High density lipoprotein cholesterol concentrations were estimated by $75 \%$ and apolipoproteins AI and B by $14 \%$ of laboratories; there were differences in specimen type and considerable diversity in procedures used for measurement.

Conclusions.-Many laboratories were unaware of current recommendations for screening for hypercholesterolaemia in the community. The present survey indicated an urgent need for the introduction of better reference methods, standardisation, and quality assurance procedures before apolipoproteins become a routine part of coronary heart disease risk assessment. $¥$ Clin Pathol 1992;45:102-5.) 